\title{
7. CALCAREOUS NANNOFOSSILS FROM DEEP SEA DRILLING PROJECT SITES 442 THROUGH 446, PHILIPPINE SEA
}

\author{
Hisatake Okada, Department of Earth Sciences, Faculty of Science, Yamagata University, Yamagata, Japan
}

\section{INTRODUCTION}

During DSDP Leg 58 nine holes were drilled at five sites in the northern Philippine Sea (Figure 1). LowerMiocene to Quaternary calcareous nannofossils were recovered from the three sites in the Shikoku Basin, whereas lower-Eocene to Quaternary assemblages were recovered at the two sites in the Daito Ridge and Basin province. Nannofossils are sporadic at all sites, except Site 445 , where abundant nannofossils occur continuously in most cores.

The age and zone assignments of the cores (Table 1), based upon light microscope observation, essentially follow Bukry $(1973,1975)$. In the Pleistocene, the names and concepts of Bukry's zones are slightly modified to accommodate results of recent studies (Haq et al., 1977; Gartner, 1977). The Emiliania overta Subzone is replaced by the Pseudoemiliania lacunosa Subzone. The Crenalithus doronicoides Zone is not divided into subzones, and its top is marked by the beginning of the acme, instead of by the first occurrence of Gephyrocapsa oceanica. In the middle Miocene, the Helicopontosphaera kamptneri Subzone is replaced by the Helicosphaera carteri Subzone.

The following nannoplankton species are considered in this report:

Amaurolithus bizzarus (Bukry, 1973) Gartner and Bukry, 1975

A. delicatus Gartner and Bukry, 1975

A. primus (Bukry and Percival, 1971) Gartner and Bukry, 1975

A. tricorniculatus (Gartner, 1967) Gartner and Bukry, 1975

Braarudosphaera discula Bramlette and Riedel, 1954

B. bigelowii (Gran and Braarud, 1935) Deflandre, 1947

Bramletteius serraculoides Gartner, 1969

Calciosolenia murrayi Gran [in Murray and Hjort], 1912

Campylosphaera dela (Bramlette and Sullivan, 1961) Hay and Mohler, 1967

Catinaster calyculus Martini and Bramlette, 1963

C. coalitus Martini and Bramlette, 1963

Ceratolithus acutus Gartner and Bukry, 1974

C. armatus Müller, 1974

C. cristatus Kamptner, 1950

C. rugosus Bukry and Bramlette, 1968

C. telesmus Norris, 1965

Chiasmolithus altus Bukry and Percival, 1971

C. bidens (Bramlette and Sullivan, 1961) Hay and Mohler, 1967

C. consuetus (Bramlette and Sullivan, 1961) Hay and Mohler, 1967

C. expansus (Bramlette and Sullivan, 1961) Gartner, 1970

C. gigas (Bramlette and Sullivan, 1961) Radomski, 1968

C. grandis (Bramlette and Riedel, 1954) Radomski, 1968

C. solitus (Bramlette and Sullivan, 1961) Locker, 1968

C. titus Gartner, 1970

Coccolithus crassus Bramlette and Sullivan, 1961

C. cribellum (Bramlette and Sullivan, 1961) Stradner, 1962

C. eopelagicus (Bramlette and Riedel, 1954) Bramlette and Sullivan, 1961
C. magnicrassus Bukry, 1971

C. miopelagicus Bukry, 1971

C. pelagicus (Wallich, 1877) Schiller, 1930

C. subdistichus (Roth and Hay, 1967) Bukry [in Bukry et al.], 1971

Coronocyclus nitescens (Kamptner, 1963) Bramlette and Wilcoxon, 1967

Cruciplacolithus staurion (Bramlette and Sullivan, 1961) Gartner, 1971

C. tenuiforatus Clocchiatti and Jerkovic, 1970

Cyclicargolithus abisectus (Müller, 1970) Bukry, 1973

C. floridanus (Roth and Hay, 1967) Bukry, 1971

C. pseudogammation (Bouché, 1962) Bukry, 1973

Cyelococcolithus formosus Kamptner, 1963

C. gammation (Bramlette and Sullivan, 1961) Sullivan, 1964

C. kingii Roth, 1970

C. leptopora (Murray and Blackman, 1898) Kamptner, 1954

C. macintyrei Bukry and Bramlette, 1969

Cyclolithus bramlettei Hay and Towe, 1962

Dictyococcites bisectus (Hay, Mohler, and Wade, 1966) Bukry and Percival, 1971

D. hesslandii Haq, 1966 (= D. scrippsae Bukry and Percival, 1971)

Discoaster adamanteus Bramlette and Wilcoxon, 1967

D. asymmetricus Gartner, 1969

D. aulakos Gartner, 1967

D. barbadiensis Tan Sin Hok, 1927

D. bellus Bukry and Percival, 1971

D. berggrenii Bukry, 1971

D. bifax Bukry, 1971

D. binodosus Martini, 1958

D. bollii Martini and Bramlette 1963

D. braarudii Bukry, 1971

D. brouweri Tan Sin Hok, 1927

D. calcaris Gartner, 1967

D. challengeri Bramlette and Riedel, 1954

D. deflandrei Bramlette and Riedel, 1954

D. druggii Bramlette and Wilcoxon, 1967

D. exilis Martini and Bramlette, 1963

D. germanicus Martini, 1958

D. hamatus Martini and Bramlette, 1963

D. intercalaris Bukry, 1971

D. kugleri Martini and Bramlette, 1963

D. lodoensis Bramlette and Riedel, 1954

D. moorei Bukry, 1971

D. neohamatus Bukry and Bramlette, 1969

D. nonradiatus Klumpp, 1953

D. pentaradiatus Tan Sin Hok, 1927

D. prepentaradiatus Bukry and Percival, 1971

D. pseudovariabilis Martini and Worsley, 1971

D. quinqueramus Gartner, 1969

D. saipanensis Bramlette and Riedel, 1954

D. signus Bukry, 1971

D. strictus Stradner, 1961

D. sublodoensis Bramlette and Sullivan, 1961

D. surculus Martini and Bramlette, 1963

D. tamalis Kamptner, 1967

D. tani nodifer Bramlette and Riedel, 1954

D. tani tani Bramlette and Riedel, 1954

D. triradiatus Tan Sin Hok, 1927

D. variabilis Martini and Bramlette, 1963

D. wemmelensis Achuthan and Stradner, 1969

Discoasteroides kuepperi (Stradner, 1959) Bramlette and Sullivan, 1961 


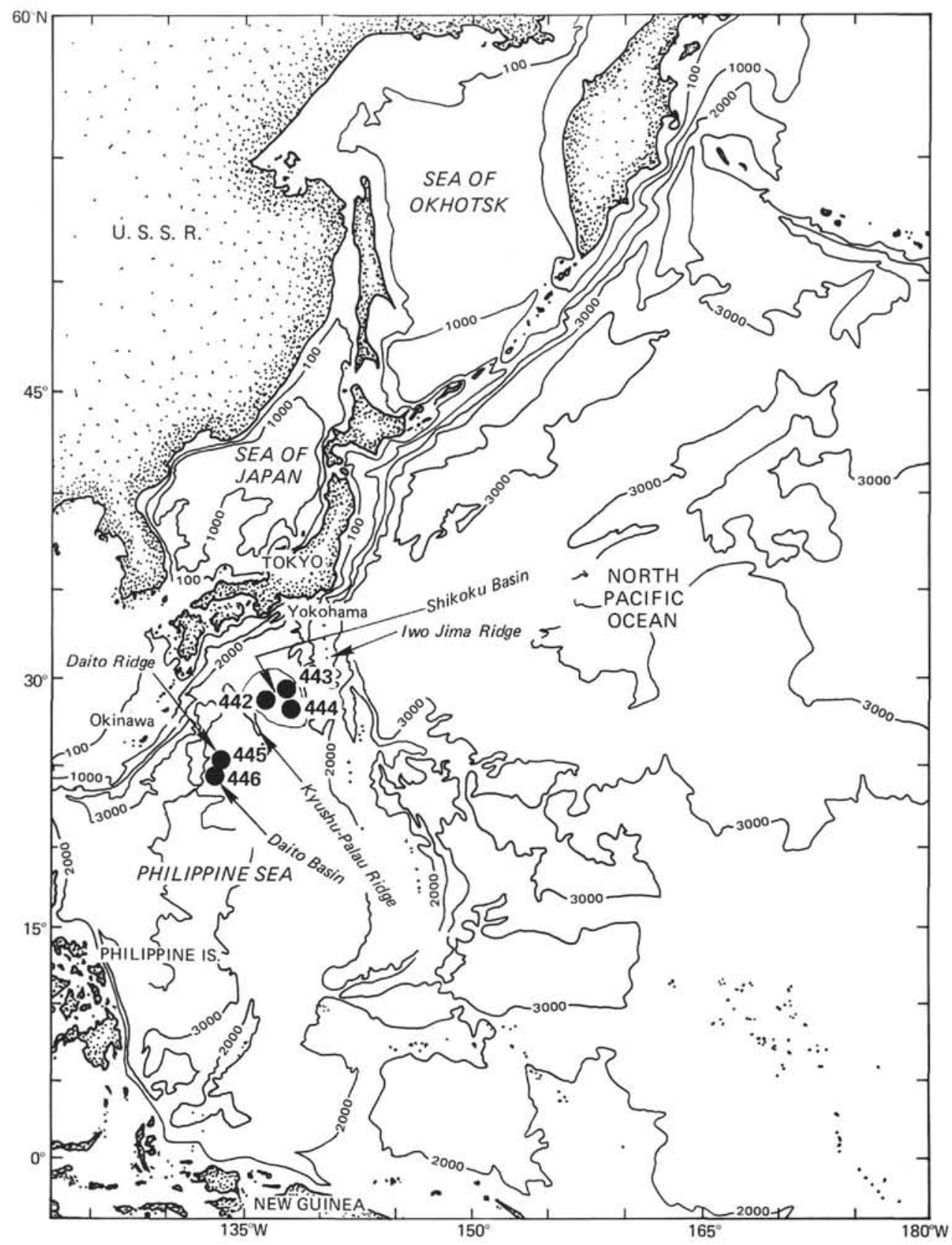

Figure 1. Location of DSDP Leg 58 sites in the Philippine Sea.

Discolithina bicaveata Perch-Nielsen, 1967

D. japonica Takayama, 1967

D. multipora (Kamptner [in Deflandre], 1959) Martini, 1965

D. plana (Bramlette and Sullivan, 1961) Levin, 1965

D. versa (Bramlette and Sullivan, 1961) Levin and Joerger, 1967

Emiliania huxleyi (Lohmann, 1902) Hay and Mohler [in Hay et al.], 1967

Ericsonia fenestrata (Deflandre and Fert) Stradner [in Haq], 1968 Florisphaera profunda Okada and Honjo, 1973

Gephyrocapsa caribbeanica Boudreaux and Hay, 1967

G. oceanica Kamptner, 1943

Helicosphaera ampliaperta Bramlette and Wilcoxon, 1967

H. carteri (Wallichi, 1877) Kamptner, 1954

H. compacta Bramlette and Wilcoxon, 1967

H. euphratis Haq, 1966

H. granulata (Bukry and Percival, 1971) Jafar and Martini, 1975

H. heezenii (Bukry, 1971) Jafar and Martini, 1975

H. intermedia Martini, 1965
H. lophota (Bramlette and Sullivan, 1961) Jafar and Martini, 1975 H. neogranulata (Gartner, 1977)

$H$. reticulata Bramlette and Wilcoxon, 1967

H. sellii (Bukry and Bramlette, 1969) Jafar and Martini, 1975

H. seminulum (Bramlette and Sullivan, 1961) Jafar and Martini, 1975

H. wallichii (Lohmann, 1902) Okada and McIntyre, 1977

Isthmolithus recurvus Deflandre [in Deflandre and Fert], 1954

Lophodolithus mochlophorus Deflandre [in Deflandre and Fert], 1954

L. nascens Bramlette and Sullivan, 1961

Micrantholithus flos Deflandre [in Deflandre and Fert], 1954

Nannotetrina fulgens (Stradner, 1960) Achuthan and Stradner, 1969

Neococcolithus dubius (Deflandre, 1954) Black, 1967

Orthorhabdus serratis Bramlette and Wilcoxon, 1967

Pedinocyclus larvalis (Bukry and Bramlette, 1969) Loeblich and Tappan, 1973

Pontosphaera syracusana Lohmann, 1902

Pseudoemiliania lacunosa (Kamptner, 1963) Gartner, 1969 
TABLE 1

Zone and Geologic Age Assignments of Leg 58 Cores Based on Calcareous Nannofossils

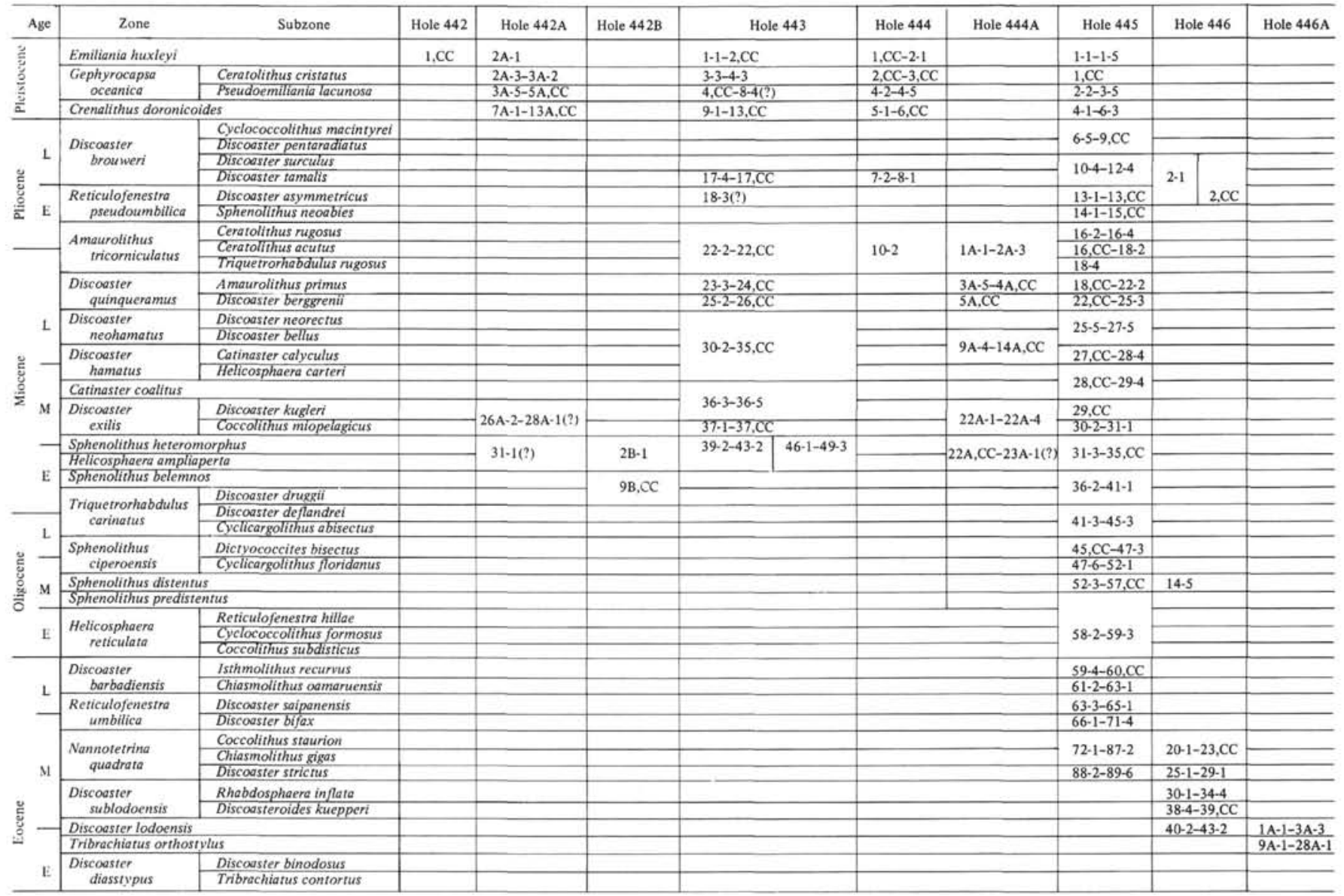

Reticulofenestra dictyoda (Deflandre and Fert, 1954) Stradner, 1968

$R$. gartneri Roth and Hay [in Hay et al.], 1967

$R$. hillae Bukry and Percival, 1971

R. pseudoumbilica (Gartner, 1967) Gartner, 1969

$R$. reticulata Perch-Nielsen, 1971

R. umbilica (Levin, 1966) Martini and Ritzkowski, 1968

Rhabdosphaera clavigera Murray and Blackman, 1898

$R$. inflata Bramlette and Sullivan, 1961

$R$. tenuis Bramlette and Sullivan, 1961

$R$. truncata Bramlette and Sullivan, 1961

Sphenolithus abies Deflandre [in Deflandre and Fert], 1954

S. ciperoensis Bramlette and Wilcoxon, 1967

S. conicus Bukry, 1971

S. dissimilis Bukry and Percival, 1971

S. distentus (Martini, 1965) Bramlette and Wilcoxon, 1967

S. furcatolithoides Locker, 1967

S. heteromorphus Deflandre, 1953

S. moriformis (Brönnimann and Stradner, 1960) Bramlette and Wilcoxon, 1967

S. neoabies Bukry and Bramlette, 1969

S. obtusus Bukry, 1971

S. predistentus Bramlette and Wilcoxon, 1967

S. pseudoradians Bramlette and Wilcoxon, 1967

S. radians Deflandré, 1952

Striatococcolithus pacificanus Bukry, 1971

Transversopontos fimbriatus (Bramlette and Sullivan, 1961) Locker, 1972

T. pulcheroides (Sullivan, 1964) Perch-Nielsen, 1971

T. pulchriporus (Reinhaldt, 1967) Sherwood, 1974

Tribrachiatus orthostylus Schamrai, 1963

Triquetrorhabdulus carinatus Martini, 1965
T. inversus Bukry and Bramlette, 1969

T. milowii Bukry, 1971

T. rugosus Bramlette and Wilcoxon, 1967

Umbellosphaera tenuis (Kamptner, 1937) Paasche [in Markali and Paasche], 1955

Umbilicosphaera sibogae (Weber-van Bosse, 1901) Gaarder, 1970

Zygrhablithus bijugatus (Deflandre, 1954) Deflandre, 1959

\section{SITE 442 (HOLES 442, 442A, AND 442B) (TABLE 2)}

Site 442 is in the west-central part of the Shikoku Basin. Hole 442 was cored only 0.5 meters to obtain necessary technical information for the re-entry operation scheduled at this site. Hole $442 \mathrm{~A}$ was continuously cored until the first basalt layer was encountered in Core 31. Continuous coring at Hole $442 \mathrm{~B}$ started about 20 meters above the basalt and recovered 20 cores, mostly basalt.

Quaternary and lower- to middle-Miocene nannofossils occur at this site. Preservation is moderately good to good in the Pleistocene and poor in the Miocene. Most fossils show various degrees of etching, without signs of overgrowth.

The Pleistocene assemblages of Sample 442-1, CC and Cores $2 \mathrm{~A}$ to $13 \mathrm{~A}$ are fairly diverse and contain numerous tropical species such as Ceratolithus cristatus and Umbilicosphaera sibogae. Although not abundant, 
TABLE 2

Distribution of Calcareous Nannofossils, Site $442^{\mathrm{a}}$

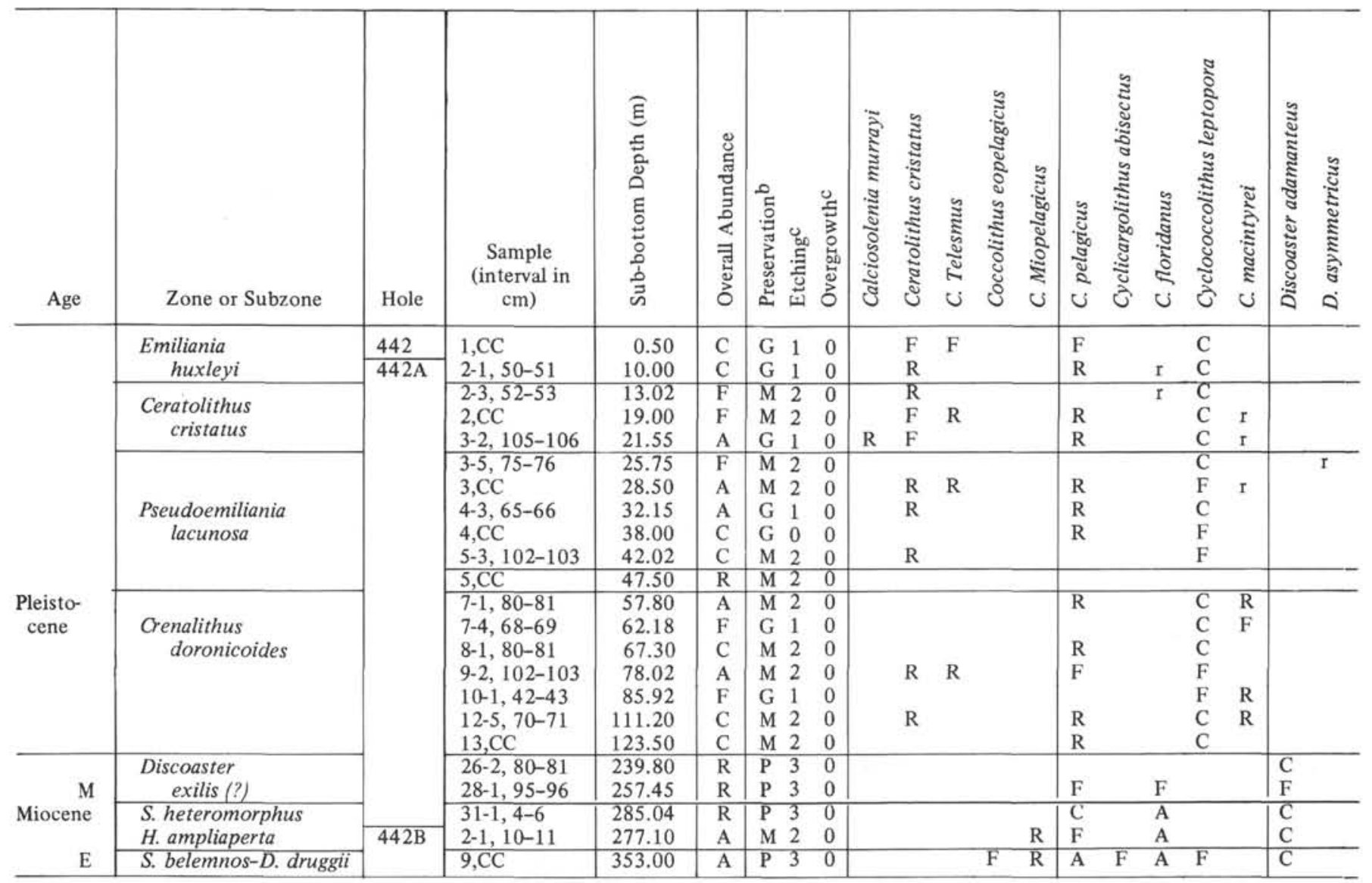

${ }^{\mathrm{a}}$ In the distribution chart: $\mathrm{A}=$ abundant (more than $10 \%$ of assemblage); $\mathrm{C}=$ common (more than $1 \%$, less than $10 \%$ ); $\mathrm{F}=$ few $(\mathrm{more}$ than $0.1 \%$ less than $1 \%$ ); $\mathrm{R}=$ rare (less than $0.1 \%$ ). For overall abundance: $\mathrm{A}=$ abundant; $\mathrm{C}=$ common; $\mathrm{F}=$ few; $\mathrm{R}=$ rare. Reworked specimens: $\mathrm{c}=$ com$\mathrm{mon} ; \mathrm{f}=\mathrm{few} ; \mathrm{r}=$ rare.

${ }^{\mathrm{b}} \mathrm{G}=$ good; $\mathrm{M}=$ moderate $\mathrm{P}=$ poor.

$\mathrm{c}_{1}=$ slight $; 2=$ moderate $; 3$ - strong.

reworked Pliocene and Miocene forms are frequently observed in this sequence.

Samples 442-1, CC and 442A-2-1, 50-51 cm yield common to abundant Emiliania huxleyi, indicating the uppermost Pleistocene to Holocene ( $E$. huxleyi Zone). The interval between Samples 442A-2-3, $52-53 \mathrm{~cm}$ and $442 \mathrm{~A}-3-2,105-106 \mathrm{~cm}$ is assigned to the $C$. cristatus Subzone; rare Pseudoemiliania lacunosa in Sample 442A-3-2, 105-106 cm are considered reworked.

Gephyrocapsa oceanica becomes common above Sample 442A-5, CC, indicating the middle-Pleistocene $P$. lacunosa Subzone for the interval between Samples $442 \mathrm{~A}-3-5,75-76 \mathrm{~cm}$ and $442 \mathrm{~A}-5$, CC. Cores $442 \mathrm{~A}-7$ to $442 \mathrm{~A}-13$, with common Gephyrocapsa caribbeanica and few $G$. oceanica, belong to the lower-Pleistocene Crenalithus doronicoides Zone. Cores $442 \mathrm{~A}-14$ to 442A-25 are barren of nannofossils.

Samples 442A-26, 80-81 cm and 442A-28-1, 95-96 $\mathrm{cm}$ yield poorly preserved, rare nannofossils, including Discoaster bollii, D. exilis, and Cyclocargolithus floridanus. The absence of Sphenolithus heteromorphus seems to indicate the $D$. exilis Zone (lower middle Miocene).
Sample 442B-2-1, 10-11 cm contains abundant and moderately well preserved nannofossils of the $S$. heteromorphus Zone or Helicosphaera ampliaperta Zone. Sample 442A-31-1, 4-6 cm, collected about $60 \mathrm{~cm}$ above a thin limestone directly overlying the first layer of basalt, contains rare nannofossils. Although $S$. heteromorphus does not occur in this sample, common Discoaster variabilis indicates the same zones identified for Sample 442B-2-1, 10-11 cm.

After drilling seven cores into basalt, pieces of yellowish-brown and dark-chocolate-brown sediment were recovered in Core 442B-9, CC. Both sediment types contain abundant, but poorly preserved nannofossils of the early Miocene. The occurrence of Discoaster druggii indicates the Sphenolithus belemnos Zone or $D$. druggii Subzone for this sample. It is not clear whether the tropical species $S$. belemnos was distributed in the Shikoku Basin or not.

\section{SITE 443 (TABLE 3)}

Site 443 is in the north-central part of the Shikoku Basin. Lower-Miocene to Quaternary nannofossils occur in 43 of 49 sedimentary cores recovered at this site. 


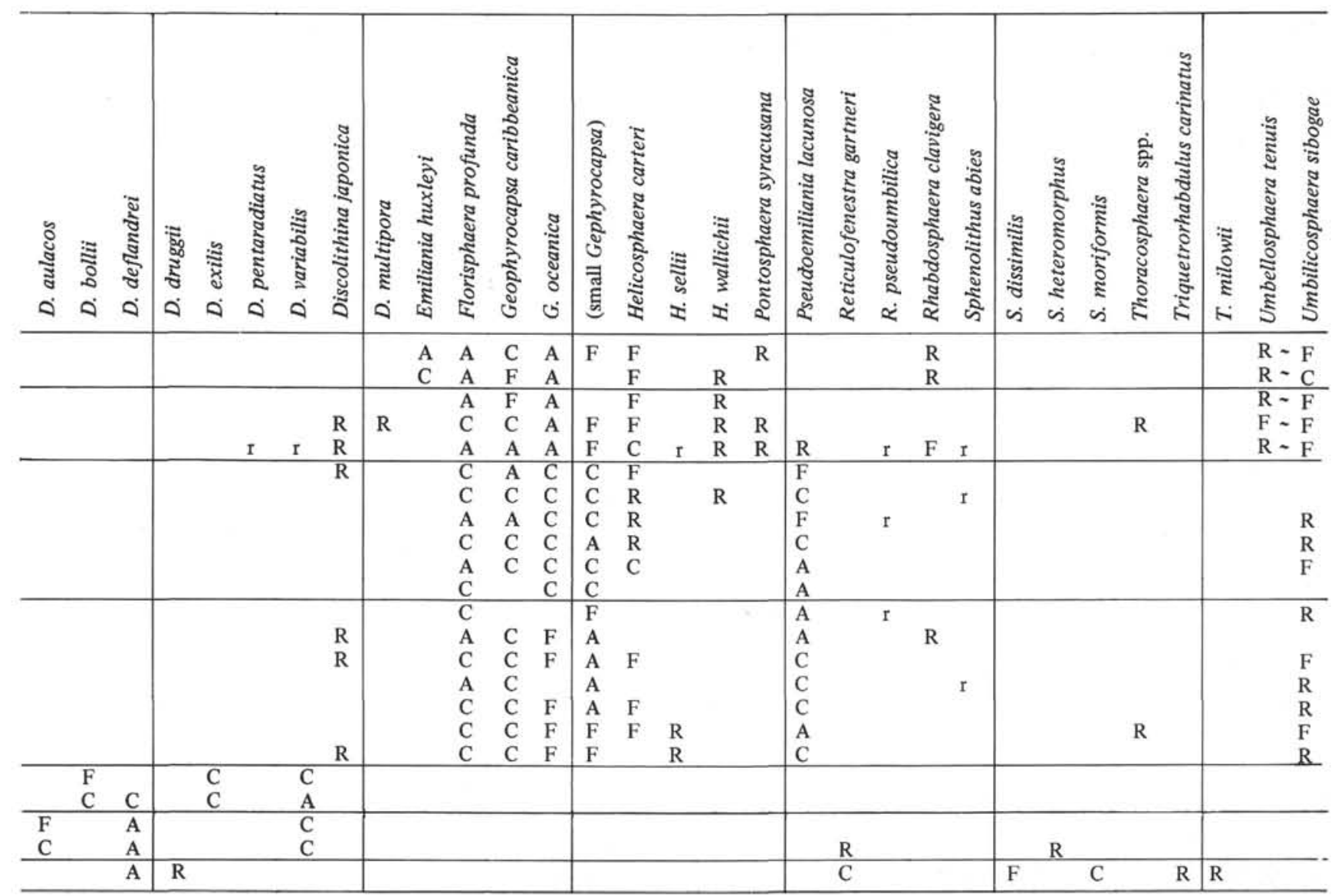

Nannofossils are generally moderately well preserved in the lower and upper Pleistocene, but their preservation is poor elsewhere. Etching prevails, and recrystallization has not taken place except immediately above the sediment/basalt contact.

Nannofossil assemblages in the Quaternary cores (443-1 to 443-13) are similar to those observed at Site 442. However, reworked Pliocene and Miocene fossils are less abundant at this site.

The first Emiliania huxleyi in Sample 443-2,CC and the disappearance of Pseudoemiliania lacunosa in Sample 443-4-3, 65-66 cm mark the bases of the E. huxleyi Zone and the Ceratolithus cristatus Subzone, respectively. Although the beginning of the acme of Gephyrocapsa oceanica is less obvious here than at Site 442 , Sample $443-8-4,52-53 \mathrm{~cm}$ is the lowest which yielded common G. oceanica.

The lower-Pleistocene Crenalithus doronicoides Zone is identified in Cores 443-9 to 443-13. Cyclococcolithus macintyrei still occurs in the upper part of this sequence. This is probably because of reworking, rather than evolution.

The occurrence of Discoaster tamalis with other Pliocene discoasters indicates the $D$. tamalis Subzone (lower upper Pliocene) for the lower sections of Core 443-17. Sample 443-18-3, 66-67 cm contains abundant nanno- fossils, including common Discoaster asymmetricus and D. tamalis, and few Reticulofenestra pseudoumbilica. This sample is assigned to the $D$. symmetricus Subzone (upper lower Pliocene).

Core 443-22 belongs to the Amaurolithus tricorniculatus Zone (uppermost Miocene and lowermost Pliocene). Rare Ceratolithus rugosus in Sample 443-22-2, $120-121 \mathrm{~cm}$ indicate the upper part of this zone $(C$. rugosus Subzone). Rare Discoaster quinqueramus in Sample 443-22,CC are regarded as reworked.

Common D. quinqueramus together with Amaurolithus primus in Cores 443-23 and 443-24 indicates the A. primuus Subzone. Cores 443-25 and 443-26 represent the Discoaster berggrenii Subzone, and Cores 443-27 to 443-29 are practically barren of nannofossils.

Cores 443-30 to 443-35 belong to the Discoaster neohamatus Zone or Discoaster hamatus Zone. The absence of key species of the upper upper Miocene, such as Discoaster hamatus, D. loeblichii, D. neorectus, and Catinaster calyculus prevents detailed age assignment of these cores. The common to few Cyclicargolithus floridanus in this interval are considered reworked.

Discoaster kugleri is also absent at this site. Because of the absence of Discoaster calcaris and the sudden decrease of $C$. floridanus, Samples 443-36-3, 38-39 cm and $443-36-5,38-39 \mathrm{~cm}$ are assigned to the Catinaster 
TABLE 3

Distribution of Calcareous Nannofossils, Site $443^{\mathrm{a}}$

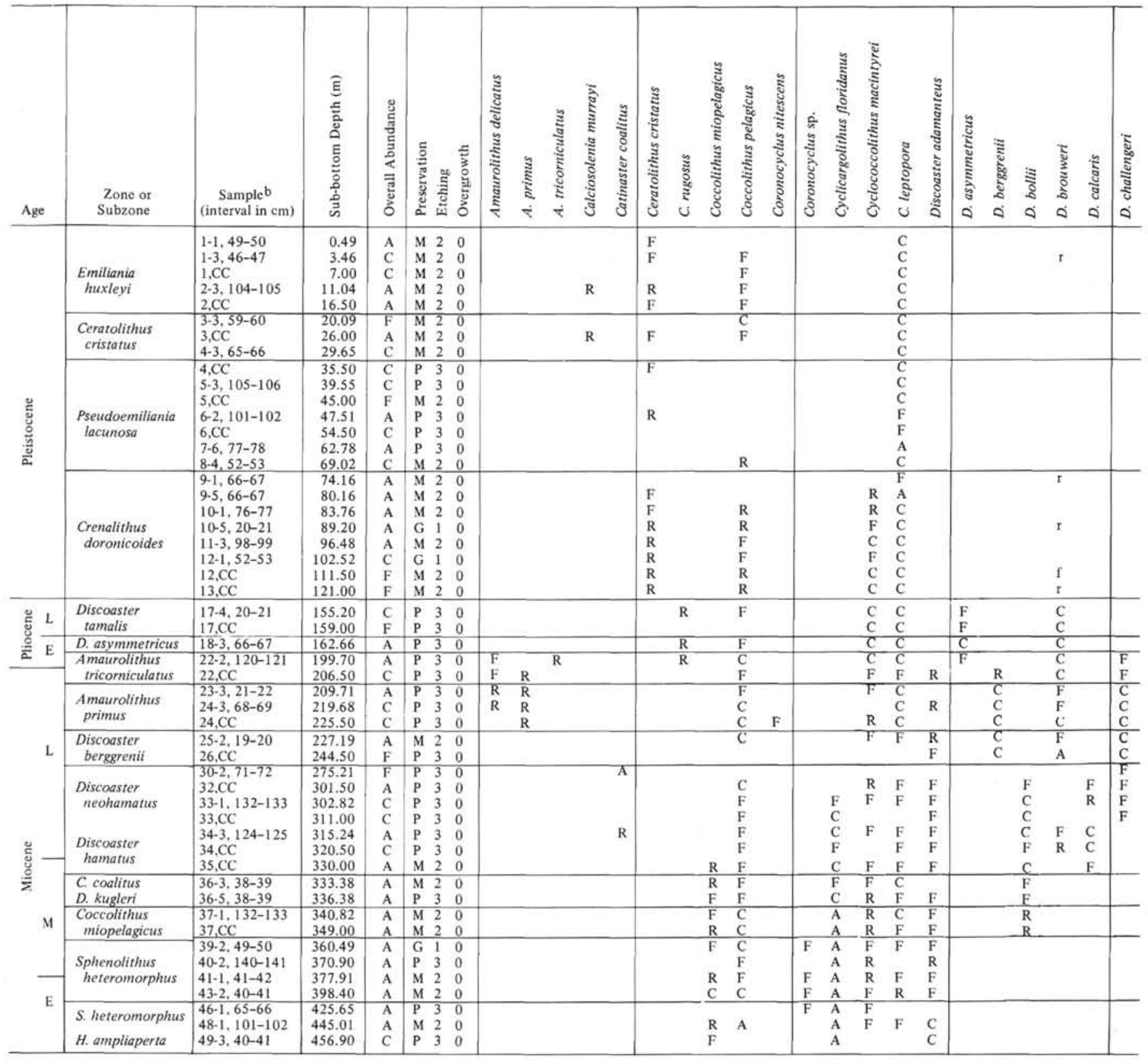

a See Table 2 for explanation of symbols.

b All from Hole 443 .

coalitus Subzone or Discoaster kugleri Subzone. The nannofossil assemblage in Core 443-37, with abundant C. floridanus and no Sphenolithus heteromorphus, is indicative of the Coccolithus miopelagicus Subzone.

Samples $443-39-2,49-50 \mathrm{~cm}$ to $443-43-2,40-41 \mathrm{~cm}$ yielded assemblages of the $S$. heteromorphus Zone. Cores $443-46$ to $443-49$ belong either to the $S$. heteromorphus Zone or to the Helicosphaera ampliaperta Zone. H. ampliaperta was not observed at this site. Although abundant $D$. deflandrei seem to indicate the $H$. ampliaperta Zone for this oldest sedimentary sequence, the possibility of reworking makes definite age identification difficult.

\section{SITE 444 (HOLES 444 and 444A) (TABLE 4)}

Site 444, 45 nautical miles southwest of Site 443, was drilled to examine the age of basement which lies on the same magnetic anomaly as that at Site 443.

Hole 444 was continuously cored through the upper sedimentary sequence to a sub-bottom depth of 91.5 meters (10 cores). At Hole $444 \mathrm{~A}$, continuous coring was resumed at 82 meters, and 27 additional cores were recovered. Lower-Miocene to Quaternary nannofossils were observed, and the assemblages were found to be similar to those of Site 443, with the exception of a few zones or subzones missing at this site. Despite the great- 
TABLE 3 - Continued

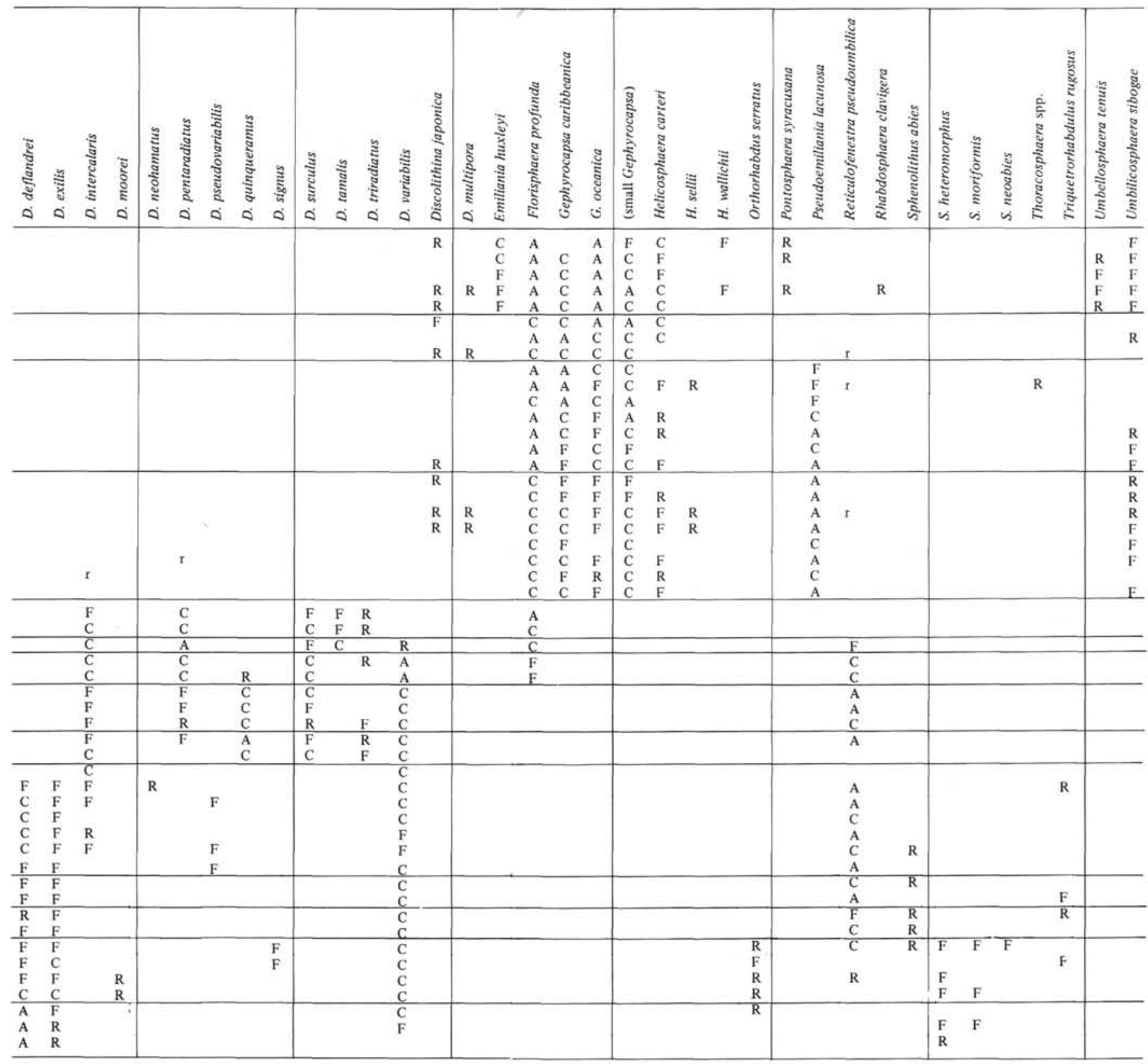

er water depth (about $500 \mathrm{~m}$ deeper than at Site 443), preservation of nannofossils is generally similar to that at Site 443 , or better in some intervals.

Pleistocene assemblages are preserved in Cores 444-1 to 444-6. Although the Pleistocene thickness is less than half that encountered at Sites 442 and 443, all Pleistocene zones and subzones were observed at this site. Reworking is minor for discoasters, but is substantial for placoliths.

Samples 444-1,CC and 444-2-1, 98-99 cm, representing the Emiliania huxleyi Zone also contain reworked Pseudoemiliania lacunosa. The abrupt decrease of $P$. lacunosa in Sample 444-3,CC is interpreted as an indication of the base of the Ceratolithus cristatus Subzone. Core 444-4, representing the $P$. lacunosa Subzone, con- tains rare to few reworked Cyclococcolithus macintyrei.

Cores 444-5 and 444-6 yield nannofossils of the lower-Pleistocene Crenalithus doronicoides Zone. As at all the Shikoku Basin sites, the lowest Pleistocene assemblage (occurrence of Gephyrocapsa caribbeanica below the first $G$. oceanica) is not recognized.

A well-preserved and diverse assemblage of the Discoaster tamalis Subzone (lower upper Pliocene) is observed in Samples 444-7-2, 37-38 cm and 444-8-1, 53-54 $\mathrm{cm}$. The three upper subzones of the Discoaster brouwe$r i$ Zone are missing. Because there is only a maximum of 2 meters of sediment that represents these subzones, a hiatus or a condensed section is suspected. If the rare $D$. tamalis in this part of the section are reworked, then part or most of Cores $444-7$ and $444-8$ could belong to 
TABLE 4

Distribution of Calcareous Nannofossils, Site $444^{\mathrm{a}}$

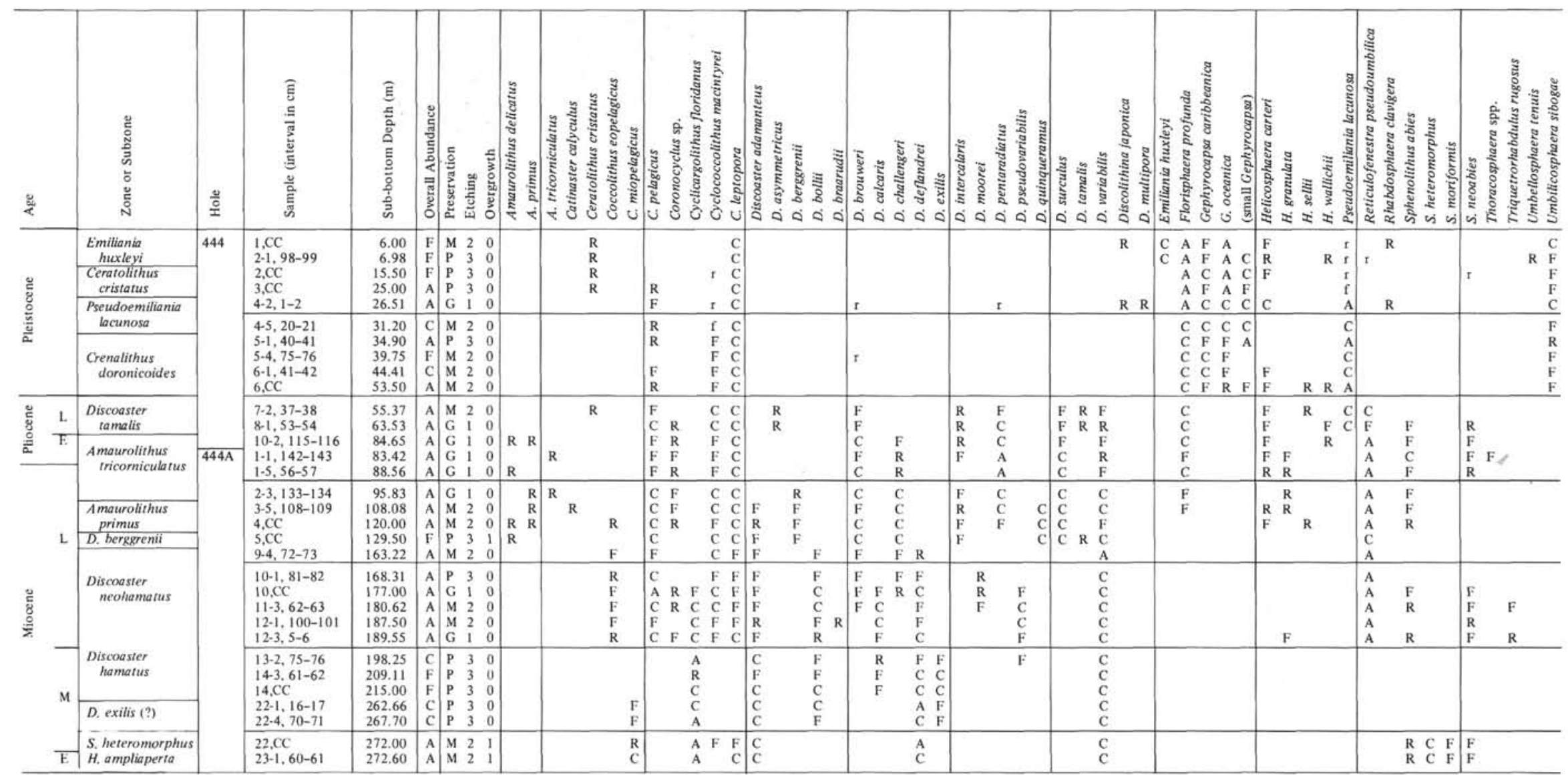

${ }^{a}$ See Table 2 for explanation of symbols. 
the upper upper Pliocene. Nannofossils are sporadic in the Pliocene, and definite conclusions are difficult to draw.

Core 444-10 and Samples 444A-1-1, 142-143 cm to 444A-2-3, 133-134 cm contain a well-preserved assemblage of the Amaurolithus tricorniculatus Zone. Samples $444 \mathrm{~A}-3-5,108-109 \mathrm{~cm}$ and $444 \mathrm{~A}-4, \mathrm{CC}$ yield an assemblage of the Amaurolithus primus Subzone (upper upper Miocene), whereas the absence of A. primus in Sample 444A-5, CC indicates the older Discoaster berggrenii Subzone. Cores 444A-6 to 444A-8 are barren of nannofossils.

Discoaster calcaris first occurs in Sample 444A$14, \mathrm{CC}$, indicating the Discoaster neohamatus Zone or D. hamatus Zone for Cores 444A-9 through 444A-14. As at Site 443, the absence of key species prevents detailed age assignment of these cores.

Cores $444 \mathrm{~A}-15$ to $444 \mathrm{~A}-18$ are barren of nannofossils, and the first basalt layer was encountered in Core 444A-19. Below this igneous layer, Cores $444 \mathrm{~A}-21$ to 444A-23 recovered more sediment. Although Core 444A21 is barren, many intervals in Core 444A-22 and Section 444A-23-1 contain abundant nannofossils.

In the upper four sections of Core 444A-22, a poorly preserved nannoflora is observed. The assemblage consists of only two placolith and five discoaster species, and the absence of $D$. calcaris and Sphenolithus heteromorphus seems to indicate the Discoaster exilis Zone (lower middle Miocene).

Nannofossils are overgrown in Sections 444A-22, CC and 444A-23-1 immediately above the second layer of basalt. Within this short interval, the degree of etching is reduced, but the severity of recrystallization greatly increases toward the sediment/basalt contact. The assemblage in Samples 444A-22, CC and 444A-23-1, 60-61 $\mathrm{cm}$ indicates the $S$. heteromorphus Zone or Helicosphaera ampliaperta Zone; thus, the oldest sediment recovered at this site is the same age as that found at Site 443.

\section{SITE 445 (TABLES 5 and 6)}

Site 445 , in a small basin in the Daito Ridge, was continuously cored to 892 meters, and 94 cores of sediment were recovered. No basalt was reached at this site, and middle-Eocene to Quaternary nannofossils were observed. Because of heavy and continuous reworking, the age assignment of cores is limited. All reworked specimens observed at this site represent a few zones prior to the time of redeposition.

Nannofossils are well preserved in the upper sequence (upper upper Miocene and above); only slight etching and negligible recrystallization were recognized. Slight etching and moderate to heavy overgrowth were observed in the lower cores. Recrystallization of nannofossils is strongest in the Oligocene and becomes less severe in the middle-Eocene turbidites.

Core 445-1 contains a late-Quaternary assemblage of the Emiliania huxleyi Zone and Ceratolithus cristatus Subzone. In addition to the lower-Pleistocene and Pliocene species, some reworked older forms, such as Cyclicargolithus floridanus and Sphenolithus moriformis, were also observed. Although the $C$. cristatus Subzone is recognized only in Sample 445-1,CC, part or all of Core 445-2 could belong to this zone if the common specimens of Pseudoemiliania lacunosa in Core 2 are reworked. The bases of the lower-Pleistocene $P$. lacunosa Subzone and the Crenalithus doronicoides Zone are recognized within Samples 445-3-5, 28-29 cm and 445-6-3, $52-53 \mathrm{~cm}$, respectively.

Samples 445-6-5, 52-53 cm through 445-12-4, 44-45 $\mathrm{cm}$ contain an upper-Pliocene assemblage of the Discoaster brouweri Zone. Florisphaera profunda first becomes abundant in the lower part of this zone. The base of the Discoaster pentaradiatus Subzone is identified in Sample 445-9,CC, but other subzone boundaries are obscured by reworking.

Cores 445-13 to 445-15 contain an assemblage of the lower-Pliocene Reticulofenestra pseudoumbilica Zone, and the base of Core 445-13 represents the boundary of subzones within this zone. Samples 445-16-2, 54-55 cm to $445-18-4,15-16 \mathrm{~cm}$ represent the Amaurolithus tricorniculatus Zone, and all three subzones were identified.

Nannofossils indicative of the upper-Miocene Discoaster quinqueramus Zone occur in Samples 44518 , CC through 445-25-3, 65-66 cm, and the first Amaurolithus primus in Sample 445-22-2, 23-24 cm indicates the base of the $A$. primus Subzone. The first occurrence of Florisphaera profunda was observed in the upper part of this subzone.

Samples $445-25-5,65-66 \mathrm{~cm}$ to $445-27-5,11-12 \mathrm{~cm}$ belong to the Discoaster neohamatus Zone. The absence of key species prevents identification of the subzones. The Catinaster calyculus Subzone (lower upper Miocene) is identified in Samples 445-27,CC to 445-28-4, $81-82 \mathrm{~cm}$. C. calyculus and C. coalitus are abundant in some samples, and Discoaster hamatus is also common in this interval.

D. hamatus and C. coalitus do not occur below Sample 445-28-2, 81-82 cm, making age assignment very difficult for the upper middle Miocene. The rare occurrence of Discoaster kugleri only in Sample 445-29, CC indicates that Samples 445-28,CC to 445-29-4, 49-50 cm belong to the Helicosphaera carteri Subzone or to the $C$. coalitus Zone.

Core 445-30 and Sample 445-31-1, 80-82 cm are assigned to the Coccolithus miopelagicus Subzone, and the few specimens of Sphenolithus heteromorphus in these samples are considered reworked.

The assemblage in Samples 445-31-3, 80-82 $\mathrm{cm}$ to 445-35, CC represents the $S$. heteromorphus Zone or the Helicosphaera ampliaperta Zone (lower middle to upper lower Miocene). Reworking and the very limited occurrence of $H$. ampliaperta prevent separation of these zones. Samples 445-36-2, 30-31 cm to 445-41-1, 42-43 $\mathrm{cm}$ represent the Sphenolithus belemnos Zone or the Discoaster druggii Subzone. The absence of S. belemnos prevents separation of these two zones at this site.

Samples $445-41-3,42-43 \mathrm{~cm}$ to $445-45-3,120-121 \mathrm{~cm}$ belong to the lowermost-Miocene Discoaster deflandrei Subzone or the upper-Oligocene Cyclicargolithus abisectus Subzone. Because of strong reworking, the Oligo- 
TABLE 5

Distribution of Neogene Calcareous Nannofossils, Site $445^{\mathrm{a}}$

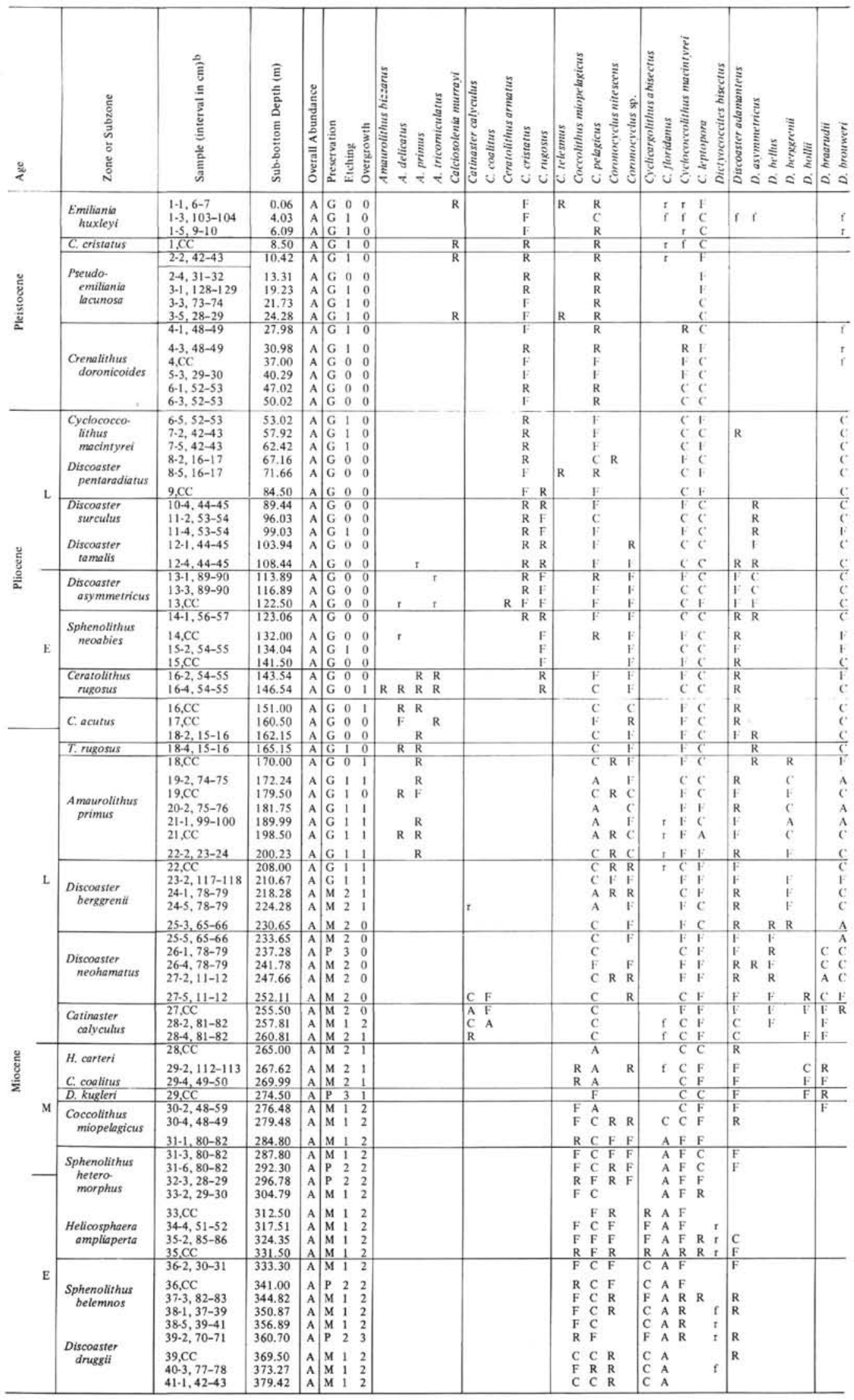

${ }^{\text {a }}$ See Table 2 for explanation of symbols. All from Hole 445. 
TABLE 5 - Continued

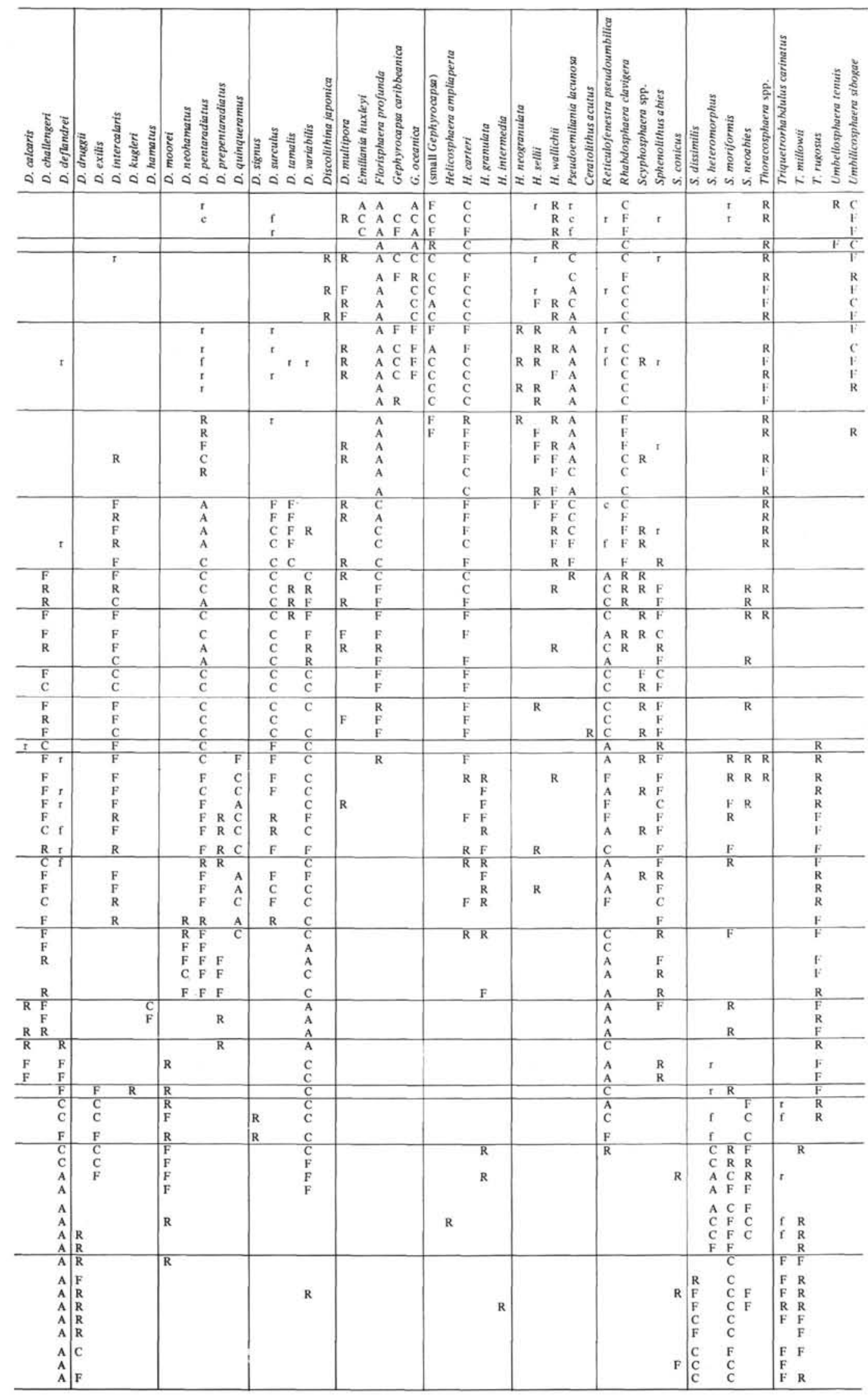


TABLE 6

Distribution of Paleogene Calcareous Nannofossils at Site $445^{\mathrm{a}}$

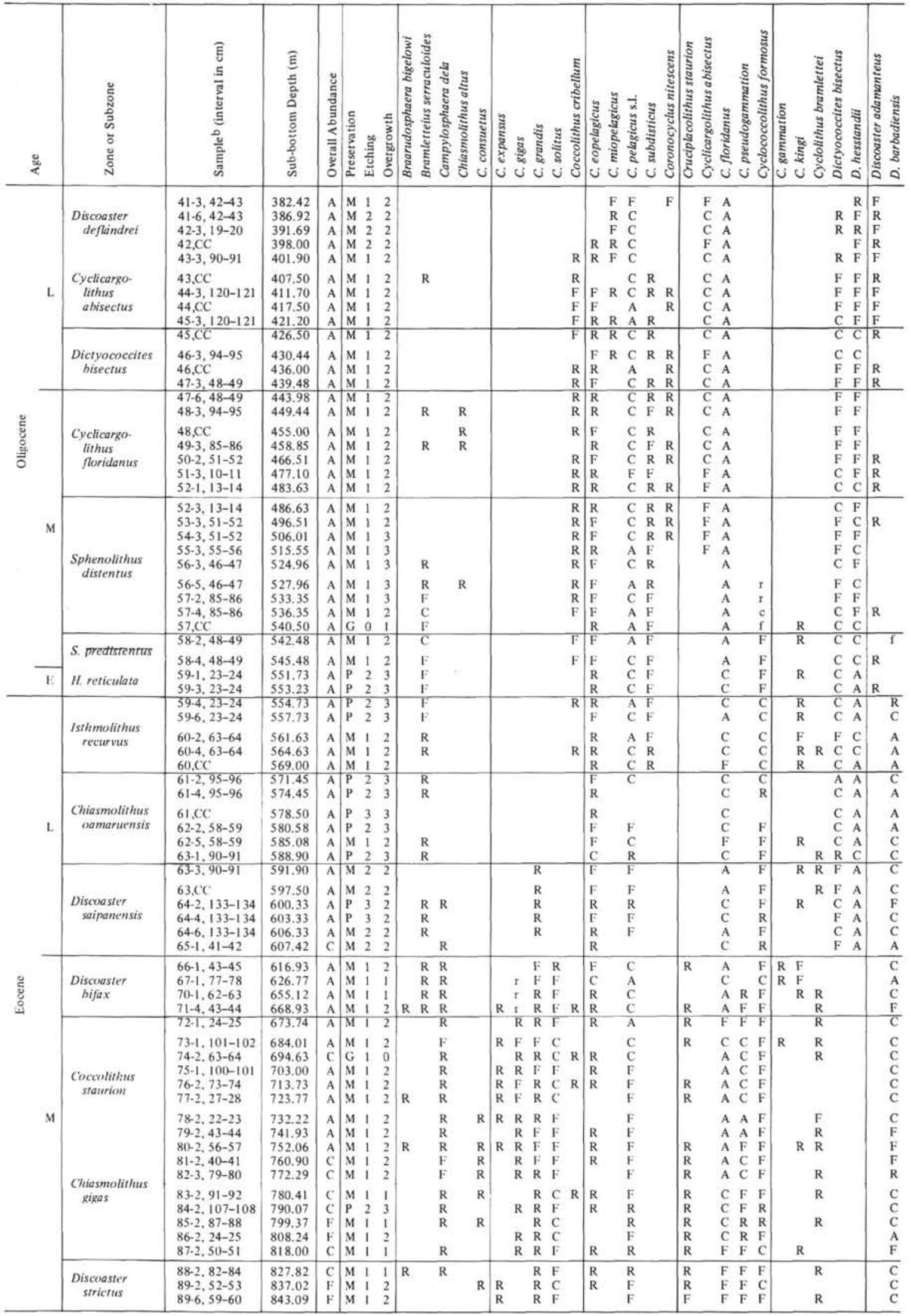

a See Table 2 for explanation of symbols.

All from Hole 445 , 
TABLE 6 - Continued

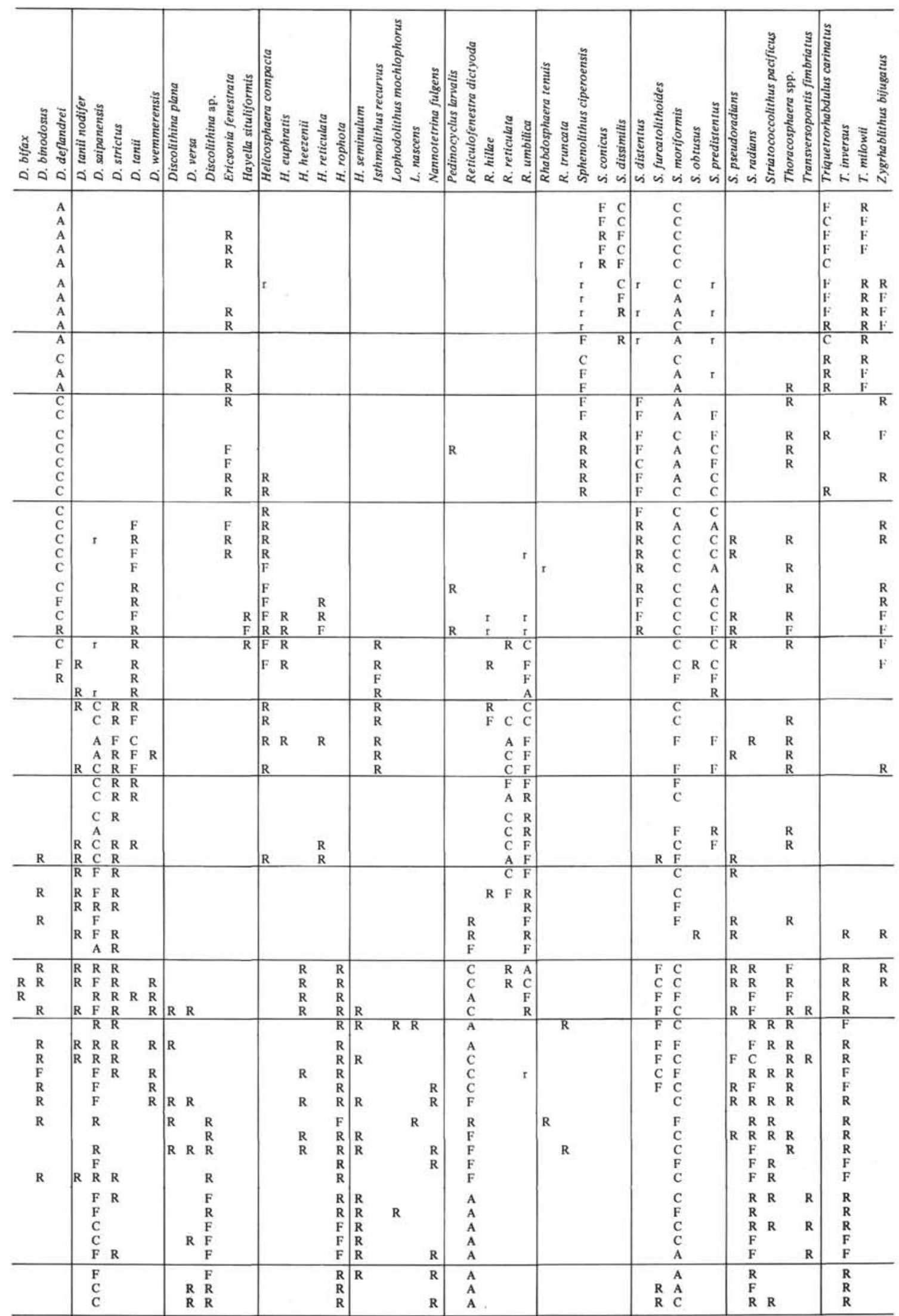


cene/Miocene boundary, marked by the end of the acme of C. abisectus, was not identified. The rare Sphenolithus ciperoensis in the lower samples are considered reworked.

The assemblage in Samples $445-45, \mathrm{CC}$ to $445-47-3$, $48-49 \mathrm{~cm}$ are indicative of the Dictyococcites bisectus Subzone (lower upper Oligocene), and Discoaster deflandrei becomes abundant here. The coexistence of $S$. ciperoensis and $S$. distentus permits assignment to the Cyclicargolithus floridanus Subzone for Samples 445-47-6, 48-49 $\mathrm{cm}$ through 445-52-1, 13-14 cm.

Samples $445-52-3,13-14 \mathrm{~cm}$ to $445-57, C C$ represent the $S$. distentus Zone (middle middle Oligocene). Reworked lower-Oligocene forms, such as Cyclococcolithus formosus, Reticulofenestra hillae, and R. umbilica, were frequently observed in the lower samples.

Core 445-58 and the upper three sections of Core 44559 yielded a mixed assemblage of the Sphenolithus predistentus Zone (lower middle Oligocene) and the Helicosphaera reticulata Zone (lower Oligocene). Strong reworking of the index species prevents more-detailed age assignment of this sequence. Although rare, Isthmolithus recurvus occurs consistently. Sporadic reworked Eocene discoasters, such as Discoaster barbadiensis or $D$. saipanensis, were also noticed. A hiatus is likely within this sequence.

The lower sections of Cores 445-59 and 445-60 yielded common to abundant $D$. barbadiensis and $D$. saipanensis, together with rare $I$. recurvus, indicating the $I$. recurvus Subzone (upper upper Eocene). Although Chiasmolithus oamaruensis does not occur at this site, the last occurrence of Chiasmolithus grandis, in Sample 445-63$3,90-91 \mathrm{~cm}$, indicates the $C$. oamaruensis Subzone for Samples 445-61-2, 95-96 cm to 445-63-1, 90-91 cm.

Samples 445-63-3, 90-91 cm to 445-65-1, 41-42 cm represent the $D$. saipanensis Subzone (lower upper Eocene). The first occurrences of Dictyococcites bisectus and $D$. hesslandii are recognized at the base of this Subzone. Preservation of nannofossils is particularly poor in the upper Eocene, and nannofossils become sporadic in the middle Eocene.

Cores 445-66 to 445-71 belong to the Discoaster bifax Subzone (upper middle Eocene). The index species is observed only in the middle part of this sequence, and the base of the subzone is identified by the first occurrence of Reticulofenestra umbilica. Reworked Chiasmolithus gigas occurs in these cores.

The first C. gigas is observed in Sample 445-87-2, $50-51 \mathrm{~cm}$, and Cores $445-72$ to $445-87$ are assigned to the Coccolithus staurion Subzone and C. gigas Subzone. Nannofossils are still abundant in the upper cores, but only common to rare in the lower cores of this sequence.

Sporadic samples with common to few nannofossils were observed in Cores 445-88 to 445-89. Rare Nannotetrina fulgens with other middle-Eocene forms indicates the Discoaster strictus Subzone (middle middle Eocene) for these two cores. The lowest four cores (445-90 to 445-94) recovered at this site are barren of nannofossils, with the exception of a few intervals in which rare specimens with no age significance occur.

\section{SITE 446 (HOLES 446, 446A) (TABLE 7)}

Site 446 is in the Daito Basin, south of the Daito Ridge. In Hole 446, 46 cores were recovered, and the first basalt was encountered in Core 41. Coring at Hole $446 \mathrm{~A}$ was resumed at a level slightly above the uppermost basalt layer, and 28 cores of sediment intruded by many basalt sills were recovered.

The occurrence of nannofossils was minimal at this site. Very sporadic occurrences representing the middle Pliocene and middle Oligocene were observed in only two of 19 upper cores. In the lower sequence, where Eocene turbidites were encountered, occurrences of nannofossils are more frequent. Preservation is moderate to poor through the nannofossil-rich samples. Dissolution is slight to moderate, whereas recrystallization is heavy, except in the Pliocene.

Core 446-1 is barren of nannofossils, but Core 446-2 contains a few moderately well-preserved fossils of the middle Pliocene. Sample 446-2-1, $53 \mathrm{~cm}$ contains Pseudoemiliania sp. aff. P. lacunosa, Reticulofenestra pseudoumbilica, Sphenolithus neoabies, Discoaster brouweri, $D$. challengeri, $D$. intercalaris, $D$. pentaradiatus, $D$. surculus, and D. variabilis, with other longrange placolith species. This sample is assigned to the Discoaster asymmetricus Subzone and the lower portion of the $D$. brouweri Zone. Reworked forms, such as Catinaster coalitus, Cyclicargolithus floridanus, Discoaster berggrenii, D. quinqueramus, and Sphenolithus heteromorphus, were also observed.

A similar assemblage (less $P$. sp. aff. $P$. lacunosa and with the addition of $D$. asymmetricus and $D$. tamalis) occurs in Sample 446-2,CC. This sample is also tentatively assigned to the $D$. asymmetricus Subzone. In addition to the reworked species already mentioned, Ceratolithus acutus, Discoaster deflandrei, D. hamatus, and $D$. moorei were also observed in this sample.

Cores 446-3 to 446-19 are barren of nannofossils, except the 10-cm-thick calcareous ooze recovered in Section 446-14-5. Sample 446-14-5, 35-36 cm contains abundant and heavily overgrown nannofossils of the middle-Oligocene Sphenolithus distentus Zone. The assemblage consists of abundant $C$. floridanus and $D$. deflandrei, with common to rare Cyclicargolithus abisectus, Coronocyclus nitscens, Dictyococcites bisectus, Discoaster tani, Sphenolithus distentus, S. predistentus, and Triquetrorhabdulus carinatus.

Cores 446-20 to 446-23 yielded common to few nannofossils. The rarity of Chiasmolithus gigus and the absence of Reticulofenestra umbilica and Discoaster bifax seem to indicate the $C$. gigas Subzone (middle middle Eocene). Because reworking is common in these cores, the overlying Coccolithus staurion Subzone is included in this part of the section. Reworked forms include Discoaster lodoensis, D. sublodoensis, and Rhabdosphaera inflata. The lowest occurrence of Nannotetrina fulgens is in Sample 446-29-1, 44-45 cm. Samples $446-25-1,17-18 \mathrm{~cm}$ to $446-29-1,44-45 \mathrm{~cm}$ therefore represent the Discoaster strictus Subzone (middle middle Eocene). Reworking is minimal in this interval. 
Nannofossils occur sporadically in Cores 446-30 through 446-39, and only four samples contain a sufficient concentration of fossils to be studied. Samples 446-30-1, 35-36 cm and 446-34-4, 25-26 cm contain common to few Discoaster sublodoensis and rare Rhabdosphaera inflata, indicating the $R$. inflata Subzone. Although preservation is poor, the flora is well diversified in these samples. Samples 446-38-4, 54-56 cm and 446-39, CC contain abundant Discoaster lodoensis and Discoasteroides kuepperi, with rare $D$. sublodoensis. The absence of $R$. inflata indicates the D. kuepperi Subzone for these samples.

Cores $446-40$ to $446-43$ and $446 \mathrm{~A}-1$ to $446 \mathrm{~A}-3$ contain an assemblage of the $D$. lodoensis Zone. Common to few Coccolithus crassus consistently occur, and Tribrachiatus orthostylus appears commonly in the lower samples.

About $10 \mathrm{~cm}$ of light-bluish-green sediment overlying about $3 \mathrm{~cm}$ of dark-green sediment was recovered as one solid piece of rock in 446-40, CC. The light-colored material contains abundant Cretaceous nannofossils, with few Eocene fossils. The dark-colored material, on the other hand, yields almost equal numbers of the Cretaceous and Eocene fossils. The Eocene assemblage in both sediments is identical to that found immediately above and below this sample, which belongs to the $D$. lodoensis Zone. The Cretaceous assemblage indicates late Albian or Cenomanian. The observed species are Cretarhabdus conicus, Cruciellipsis chiastia, Eiffellithus turriseiffeli, Parhabdolithus angustus, P. asper, $P$. embergeri, Podorhabdus albianus, Prediscosphaera cretacea, Toranolithus orionatus, Watznaueria barnsae, $W$. communis, and Zygodiscus diplogramus.
Thin layers of sediments between basalt layers in Cores $446 \mathrm{~A}-4$ to $446 \mathrm{~A}-8$ are barren of nannofossils. Common to few nannofossils occur sporadically in Cores $446 \mathrm{~A}-9$ to $446 \mathrm{~A}-28$, which consist of many alternating basalt and sedimentary rock layers. The absence of $C$. crassus and the commonness of $D$. lodoensis, $D$. kuepperi, and $T$. orthostylus indicate the $T$. orthostylus Zone (upper lower Eocene) for the oldest sediment recovered at this site.

\section{ACKNOWLEDGMENTS}

I thank Dr. B. U. Haq, Woods Hole Oceanographic Institution, and Dr. H. R. Thierstein, Scripps Institution of Oceanography, for their constructive reviews of this report.

\section{REFERENCES}

Bukry, D., 1973. Low latitude coccolith biostratigraphic zonation. In Edgar, N. T., Saunders, J. B., et al., Init. Repts. DSDP, 15: Washington (U. S. Govt. Printing Office), pp. 685-703.

1975. Coccolith and silicoflagellate stratigraphy, northwestern Pacific Ocean, Deep Sea Drilling Project Leg 32. In Larson, R. L., Moberly, R., et al., Init. Repts. DSDP, 32: Washington (U. S. Govt. Printing Office), pp. 677-701.

Gartner, S., 1977. Calcareous nannofossil biostratigraphy and revised zonation of the Pleistocene. Mar. Micropaleont., 2, 1-25.

Haq, B. U., Berggren, W. A., and Van Couvering, J. A., 1977. Corrected age of the Pliocene/Pleistocene boundary. Nature, 269, 483-488. 
TABLE 7

Distribution of Eocene Calcareous Nannofossils, Site $446^{\mathrm{a}}$

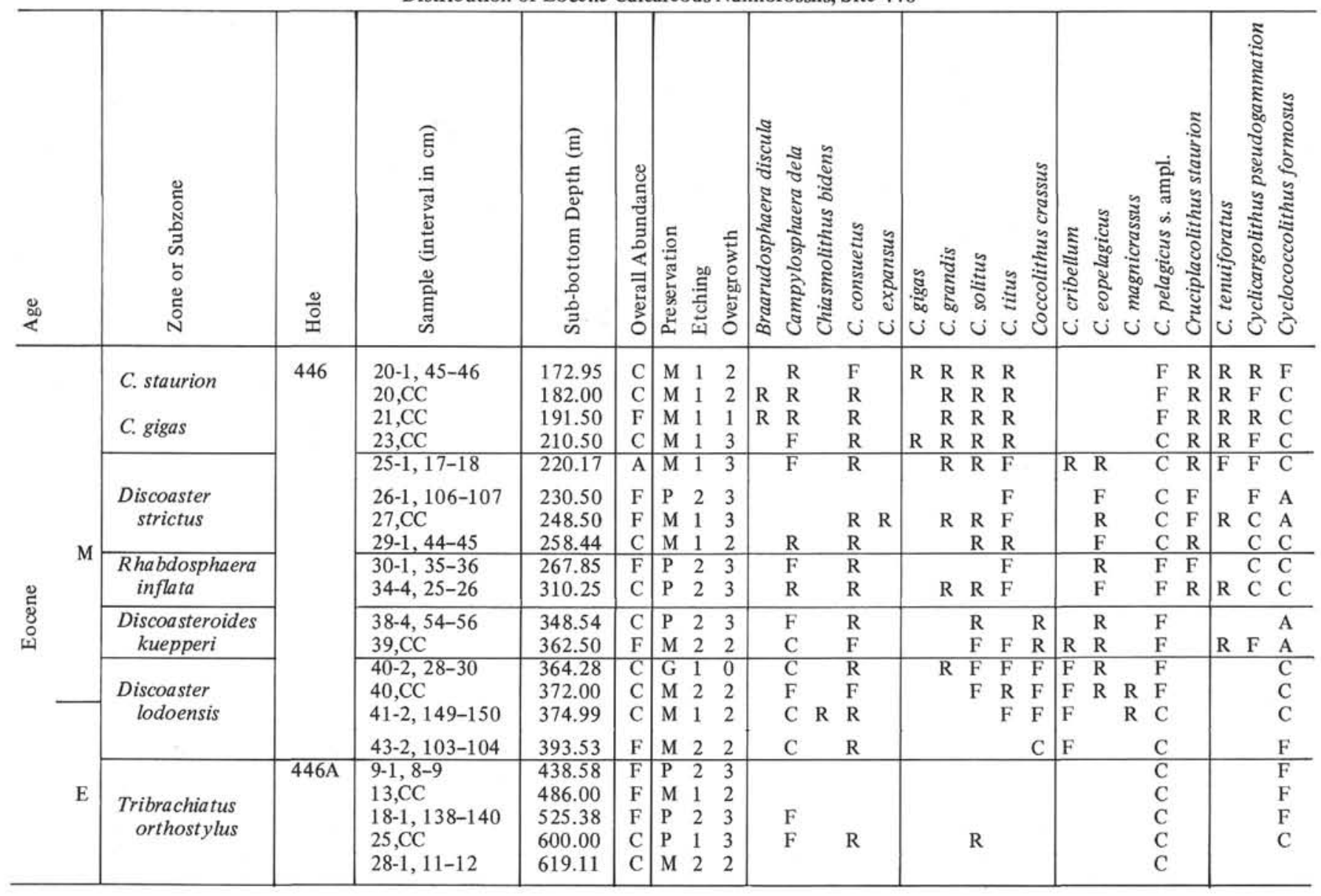

${ }^{\mathrm{a}}$ See Table 2 for explanation of symbols. 
TABLE 7 - Continued

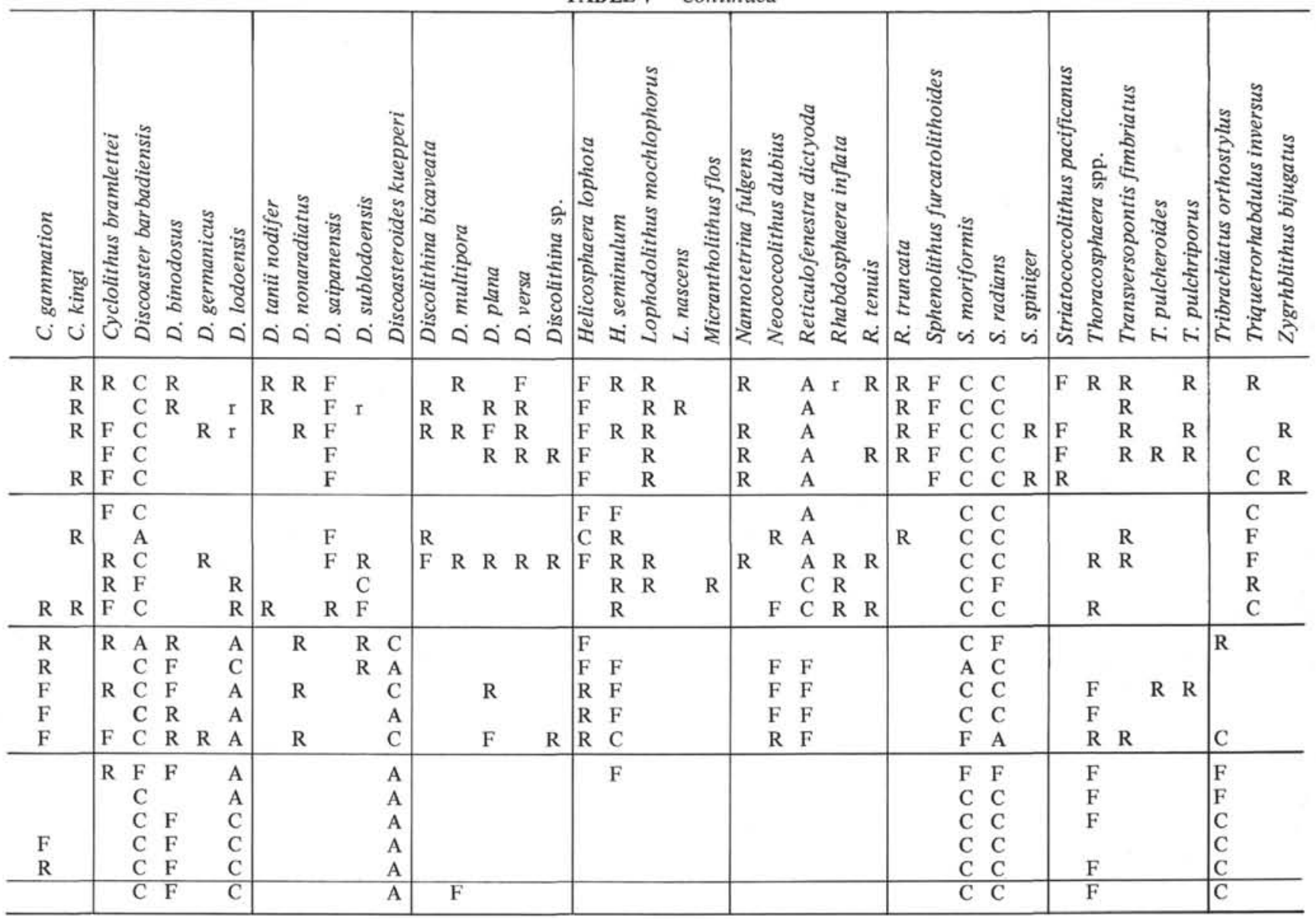

